\title{
LATE PLEISTOCENE LACUSTRINE SEDIMENTS AND THEIR RELATION TO RED SOILS IN THE NORTHEASTERN MARGIN OF THE DINARIC KARST
}

\author{
POZNO PLEISTOCENSKI JEZERSKI SEDIMENTI IN NJIHOVA \\ POVEZAVA Z RDEČIMI TLEMI NA SEVEROVZHODNEM ROBU \\ DINARSKEGA KRASA
}

\author{
Nadja ZUPAN HAJNA ${ }^{1 *}$, Bojan OTONIČAR ${ }^{1}$, Petr PRUNER $^{1,2}$, Metka CULIBERG $^{3}$, \\ Jaroslav HLAVÁČ ${ }^{2,5}$, Oleg MANDIĆ ${ }^{4}$, Roman SKÁLA² \& Pavel BOSÁK ${ }^{1,2}$
}

\begin{abstract}
UDC 551.435.8:551.435.25(497.434)"628.62" Nadja Zupan Hajna, Bojan Otoničar, Petr Pruner, Metka Culiberg, Jaroslav Hlaváć, Oleg Mandić, Roman Skála \& Pavel Bosák: Late Pleistocene lacustrine sediments and their relation to red soils in the Northeastern margin of the Dinaric Karst

A large karst doline at section Hrastje - Lešnica in the Dolenjska region (SE Slovenia) was uncovered during the construction of Slovene highway No. A2. Its fill consists of brownish-yellow clay to silt with plant remains and ferrugineous coatings after root casts and gastropods (paleosol horizon) in the bottom, and overlying thick lacustrine laminated grey clayey sediments which were partly rubified. Brownish-yellow clay to silt contains quartz, chlorite, muscovite and feldspars transported as external clastic material from evolved karst and non-carbonate landscapes from surroundings into the site. The material is well weathered only in the area of the paleosol horizon. The strongly impoverished malacocoenosis indicates any Quaternary warm phase characterized by light semi-open forest with patches of open ground habitats. Only the last paleomagnetic sample in the bottom of sediment sequence shows reverse polarity of magnetic field and represents the geomagnetic excursion, i.e., the Blake excursion at ca 120-112 ka (MIS 5e), rather than Brunhes/Matuyama boundary at $0.78 \mathrm{Ma}$ (MIS 19). Thick lacustrine laminated grey clayey sediments above
\end{abstract}

\begin{abstract}
Izvleček UDK 551.435.8:551.435.25(497.434)"628.62" Nadja Zupan Hajna, Bojan Otoničar, Petr Pruner, Metka Culiberg, Jaroslav Hlaváć, Oleg Mandić, Roman Skála \& Pavel Bosák: Pozno pleistocenski jezerski sedimenti in njihova povezava $z$ rdečimi tlemi na severovzhodnem robu Dinarskega krasa

Na Dolenjskem krasu je bila med graditvijo trase A2 slovenskega avtocestnega križa na odseku Hrastje-Lešnica razgaljena večja vrtača. V spodnjem delu je bila povsem zapolnjena $\mathrm{z}$ rjavkastorumenim sedimentom glinene do meljaste frakcije, $v$ zgornjem delu pa $\mathrm{z}$ debelim zaporedjem laminiranega sivega glinenega sedimenta, ki je bil ponekod rahlo rubificiran. Rjavkasto rumeni glineni do meljasti sediment na dnu vrtače, $v$ katerem so posamezni rastlinski ostanki, s koreninami povezane ferigene skorje in gastropodi (paleotalni horizont), vsebuje kremen, klorit, muskovit in plagioklaze. Ti so bili preneseni v vrtačo kot klastični material $z$ bližnjih območij razvijajočega se kraškega in nekarbonatnega (fluvialnega) površja. Dobro preperel material je le v območju paleotalnega horizonta. Močno osiromašena malakocenoza nakazuje eno od toplih faz kvartarja, ko so prevladovali svetli gozdovi z redkimi drevesi in jasami odprtih talnih habitatov. Samo zadnji od paleomagnetnih vzorcev na dnu raziskanega sedimentnega zaporedja kaže reverzno polarnost magnetnega polja. Menimo, da ta reverzna polarnost kaže na t. i. Blakeovo geomagnetno ekskurzijo pred cca 120.000 in 112.000 leti (MIS
\end{abstract}

\footnotetext{
${ }^{1}$ ZRC SAZU Karst Research Institute, Titov trg 2, 6230 Postojna, Slovenia; zupan@zrc-sazu.si; e-mail: otonicar@zrc-sazu.si

${ }^{2}$ Institute of Geology of the Czech Academy of Sciences, Rozvojová 269, 16500 Praha 6, Czech Republic; e-mail:pruner@gli.cas; skala@gli.cas.cz; bosak@gli.cas.cz

${ }^{3}$ ZRC SAZU Jovan Hadži Institute of Biology, Zagorica 20, 1292 Ig, Slovenia

${ }^{4}$ Geological-Paleontological Department, Natural History Museum Vienna, Burgring 7, A-1010 Vienna, Austria; e-mail: oleg.mandic@NHM-WIEN.AC.AT

${ }^{5}$ Department of Zoology, Museum of Natural History, National Museum, Václavské náměstí 68, 11579 Praha 1, Czech Republic; e-mail: jaroslav.hlavac@nm.cz

* Corresponding author: e-mail: zupan@zrc-sazu.si
}

Received/Prejeto: 07.11.2018

DOI: https://doi.org/10.3986/ac.v48i2.7080 
are also dominated by quartz, muscovite, chlorite and feldspar. That overlying sediment was almost unweathered (content of feldspars, muscovite and chlorite); it was only slightly rubified on its surface, in middle part of the section and at the contact with the underlying karstified limestone slope of the depression. The grey sediment has a different mineralogical composition than underlying soils (e.g., lack of quartz, chlorite) and non-carbonate residue of the host limestone. Therefore, the grey sediments could not serve as a parent (source) material for terra rossa formation in the broader area (i.e., polygenetic red soils developed in paleoclimate related to current Mediterranean climatic conditions). Laminated grey sediment was deposited in a rather cold climate. Relatively poor palynospectra may indicate transport of pollen grains out of the depocentre with flowing water and/or the rapid deposition. The latter is supported by insufficiently centered paleosecular variations. Plant assemblages indicate that the dominant cover of the surrounding landscape was temperate climatic zone riparian forest with some quite humid environment as wetlands and ponds on periodically flooded plain. The regional correlation, based especially on an abundance of Fagus, indicates the deposition at the beginning of the last glacial cycle (Würmian) in its warmer substage - MIS 5c (ca 105-95 ka). All paleomagnetic samples from this part of the sediment section show normal magnetization and negligible clockwise rotation of $1.8^{\circ} \pm 4.7^{\circ}$.

Key words: karst sediments, mineralogy, gastropods, palynology, paleomagnetism, paleoenvironment, Dolenjska region, Slovenia. 5e) in ne meje Brunhes/Matuyama pred 780.000 leti (MIS 19). Tudi v debelem zaporedju sivih laminiranih glinastih jezerskih sedimentov prevladujejo med minerali kremen, muskovit, klorit in glinenci. Glede na ohranjenost glinenih mineralov, muskovita in klorita sklepamo, da so ti sedimenti skoraj neprepereli; rahlo so rubificirani le na površju, $v$ osrednjem delu profila in na stiku z zakraselo podlago vrtače. Mineraloška sestava sivih sedimentov je drugačna kot v spodaj ležečem talnem horizontu, kjer je manj kremena in klorita, razlikuje pa se tudi od nekarbonatnega preperinskega ostanka apnenčaste prikamnine. Kot tak torej siv sediment ni izvorni material na sosednjih območjih pogoste terre rosse (poligenetska rdeča tla, razvita v pleoklimatskih razmerah, podobnih današnjemu mediteranskemu podnebju). Laminirani sedimenti so se odložili v razmeroma hladnem obdobju. Dokaj siromašen palinospekter lahko kaže po eni strani, da so bila pelodna zrna odstranjena iz depocentra s tekočo vodo, po drugi pa na visoko hitrost sedimentacije. V prid temu procesu pritrjujejo tudi premalo centrirane paleosekularne variacije. Rastlinske združbe nakazujejo, da je bila bližnja okolica v glavnem porasla z obrežnimi gozdovi zmernega podnebnega pasu, kjer so se v humidnih obdobjih poplavljenih ravnic občasno pojavljala tudi mokrišča in manjše ojezeritve. Regionalne korelacije, ki temeljijo predvsem na veliki količini pelodov bukve (Fagus) kažejo, da so se sivi glinasti sedimenti odlagali v toplejšem obdobju na začetku zadnjega poledenitvenega cikla (Würm) med t. i. MIS $5 \mathrm{c}$ pred okoli 105.000 do 95.000 leti. Vsi paleomagnetni vzorci tega dela sedimentnega profila kažejo normalno magnetizacijo in zanemarljivo rotacijo $1,8^{\circ} \pm 4,7^{\circ} \mathrm{v}$ smeri urinega kazalca.

Ključne besede: kraški sedimenti, mineralogija, polži, palinologija, paleomagnetizem, paleookolje, Dolenjska, Slovenija.

\section{INTRODUCTION}

Thick red soils of the Dolenjska region (SE Slovenia; Fig. 1) are predominantly determined as relict soils (Grčman et al. 2015). Their origin and relationship to underlying carbonates and existing karst relief has been, and still is, the subject of discussion. Different opinions were related to the nature of parent material and origin of the red soils (terra rossa; Gregorič 1969; Gams \& Vrišer 1998; Rejšek et al. 2012). Terra rossa-type red soils are composed of reddish clayey to silty material covering karst landscapes in hot/warm climates such as those in the Mediterranean part of Dinaric Karst.

Terra rossa may have formed exclusively from the insoluble residue of carbonates in some isolated karst, but more often it comprises a variety of parent materials, especially aeolian siliciclastic and/or volcanic dust, volcanic and/or clastic sedimentary rocks (e.g., Andrusov et al. 1958; Durn 2003). Most authors believe that terra rossa represents polygenetic relict soil formed during the Tertiary and/or warm and humid periods of Quaternary (see Fedoroff \& Courty 2014).
The low karst of Dolenjska (sensu Gams 1974 or Kranjc 1990; Fig. 1) is covered by Plio-Quaternary deposits with variable lithologies (Grimšičar 1954; Buser 1974; Gams 1974; Pleničar et al. 1977; Habič 1992; Zupan Hajna 1992; Markič 2009). Thick layers of red deposits prevail (Gregorič 1969; Gams \& Vrišer 1998). Although "reddish-brown soils" form a distinctive feature of the Dinaric karst landscapes, no integrated study has been performed in the Dolenjska region; their source has been still unknown as well. Based on few analyses, Gregorič (1969) and Rejšek et al. (2012) interpreted them as in situ or partly re-deposited weathering products covering carbonate rocks. In addition, also relatively homogenous yellowish sands laterally and vertically alternate with clayey material or fill irregularities of karst surface (mainly subcutaneous shafts and karren; e.g., Habič 1992; Zupan Hajna 1992; Knez \& Slabe 2006) in the same regions (see Otoničar et al. 2006). Grey montmorillonitic ("bentonite") clays are locally reported on karst relief and were interpreted as weathered residues of volcanoclas- 


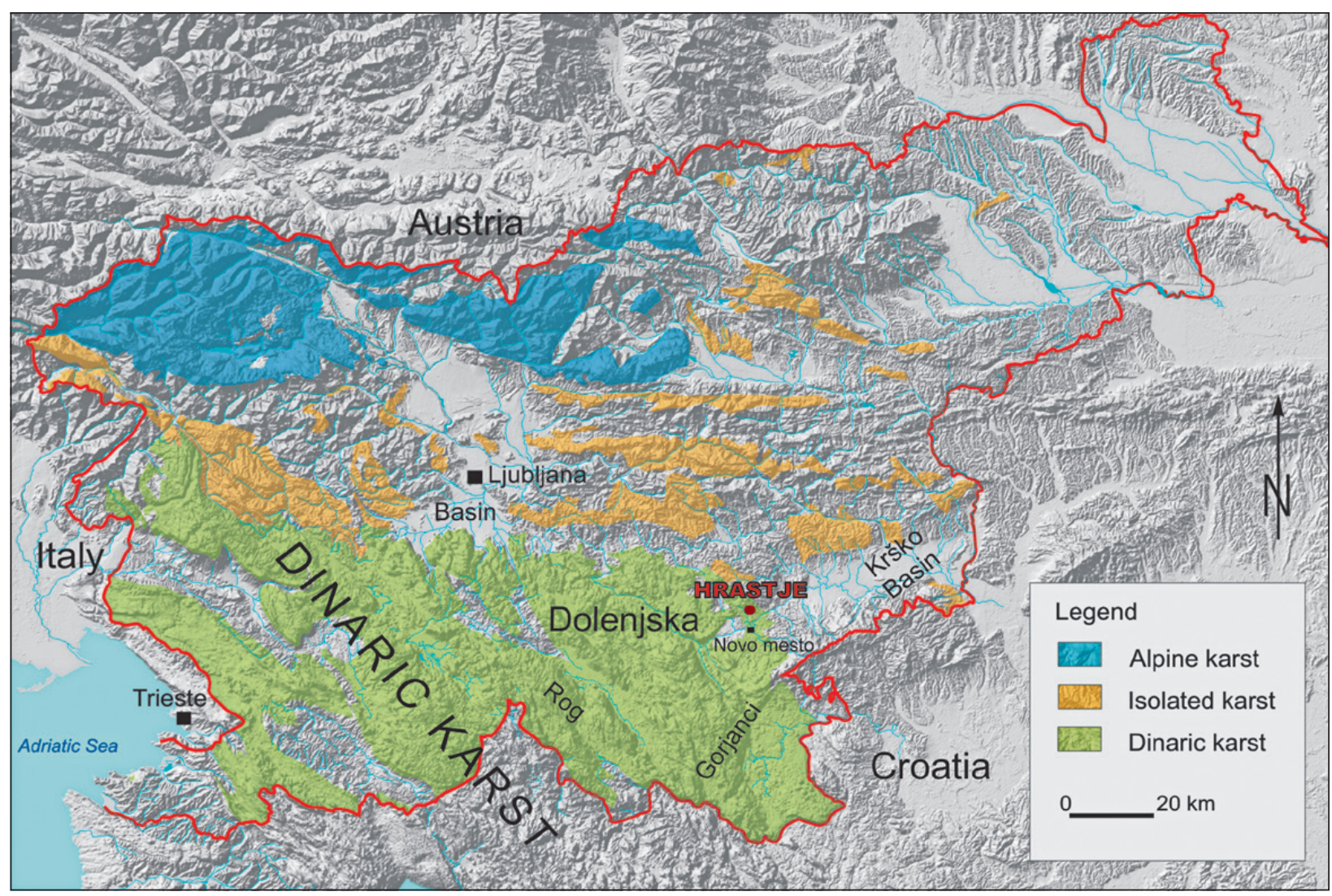

Fig. 1: Location of the studied karst sediments at Hrastje (red dot) in the Dolenjska region, which represents the NE part of Dinaric karst. Source of DEM data: Geodetski oddelek ARSO.

tic material (Grimšičar 1954; Pleničar et al. 1977). They had been excavated for the ceramic industry some $3 \mathrm{~km}$ from our studied site north of Novo mesto (Pleničar et al. 1977). Chert pebbles derived from different Mesozoic carbonate host rocks are relatively common in such clays or loams in places (Buser 1974; Pleničar et al., 1977; Zupan Hajna 1992; Otoničar et al. 2013). Grimšičar (1954) noted that bentonitic clays should be older than Pliocene fluvial sands of the Krško Basin.

Mineralogical analyses of various quartz-containing sediments from the cover of the Dolenjska karst indicate that at least two types of quartz occur in sediments: (i) weathered residue of dissolution of chert-containing carbonate rocks, and (ii) allogenic quartz sand weathered to a different degree (Zupan Hajna 1992). All of the above-mentioned sediments may represent potential source of red soils in the Dolenjska region.
The construction of highway A2 Karavanke Obrežje (Austria - Croatia) north of Novo mesto at section Hrastje - Lešnica $\left(45^{\circ} 51^{\prime} 11.07^{\prime \prime} \mathrm{N}\right.$; 15 $08^{\circ} 36.21^{\prime \prime} \mathrm{E}$; Fig. 1) uncovered laminated sediments filling a large karst depression (a doline). The central part of the doline was filled with grey to locally greenish-grey laminated and thinly-bedded clayey deposits (Fig. 2). They clearly contrasted to thick reddish-brown homogenous soils that cover karstified Mesozoic carbonates in the nearby vicinity and in the wider region. Nevertheless, the grey sediments reveal a gradual lateral transition through brownish-grey and mottled horizon to reddish-brown clayey deposit at the contact with red soils and the weathered limestone slope of the depression (Fig. 2).

Our working hypothesis was based on the assumption that the grey non-weathered laminated sediments might represent the source material for thick red soil -

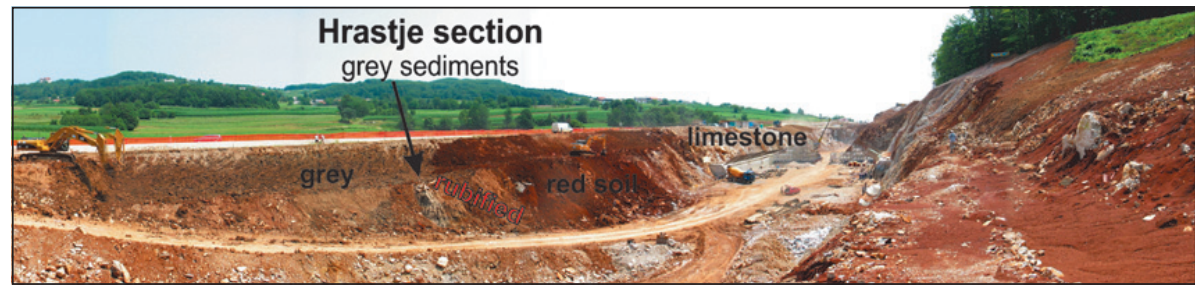

Fig. 2: Construction of the highway north of Novo mesto has exposed laminated grey sediments, which were surrounded by red soils developed on subcutaneous karst relief. 




Fig. 3: Geological map of the studied area (upper; after Otoničar et al. 2006) and digital relief model of location area (lower; on both studied sequence Hrastje is marked by red dot. Source: Geology - OGK 1:100000 Novo mesto, Geološki Zavod Slovenije (Pleničar et al 1977); DEM data - Lidar data, Geodetski oddelek ARSO. Legend: 1 - Massive coarse-crystalline dolomite and limestone; Lower part of Upper Triassic; 2 - Thick bedded Main Dolomite; Upper Triassic; 3 - Micritic and oolitic limestone and bituminous dolomite; Lower Jurassic; 4 - Reef limestone with corals and stromatoporids; Lower part of Upper Jurassic; 5 - Oolitic and micritic limestone; upper part of Upper Jurassic; 6 - Red clayey limestone to marlstone; Upper Cretaceous; 7 - Alternation of marlstone, claystone and sandstone -flyschoid clastics; Upper Cretaceous; 8 - Brown clay, terra rossa and loam; Pliocene and Quaternary; 9 - Fluvial sediments (gravel, sand, silt and clay); Quaternary; 10 - Fault; 11 - Highway profile No. (HP). 
of the terra rossa type. Our hypothesis was tested with mineralogical, pollen, malacofauna, and paleomagnetic analyses of the sediments. We were also interested in the age and paleoenvironmental conditions of the terra rossa origin and the grey laminated sediments' deposition.

\section{GEOGRAPHY \& GEOLOGICAL SETTING}

The Dolenjska region covers the area between the Ljubljana and Krško Basins (Fig. 1). It belongs to the most northeastern margin of the Dinaric Karst and is rich in karst forms (karren fields, dry valleys, dolines and shallow uvalas). Relatively smooth un-dissected slopes of elongated hills point to vertical underground drainage. Although horizontal caves are almost absent, open shafts in the bottom of depressions below relatively thick clayey soils (so-called hidden shafts: Klimchouk et al. 1996) may indicate significant subsurface karstification. Mainly low-energy relief has been developed on tectonically highly deformed Mesozoic carbonate (predominantly Jurassic and Triassic) and clastic successions (mainly Upper Cretaceous to Early Eocene "flyshoid" sequences); see Fig. 3. Miocene (not in the nearby area) or younger overlying formations are separated from Mesozoic rocks with disconformities. The distribution and thickness of Cenozoic formations varies substantially over the area.

So-called Plio-Quaternary deposits of the Dolenjska region represent a mapping unit in different geological maps (i.e., sheet Novo mesto: Pleničar et al. 1977; Slovene soil map: Grčman et al. 2015). They commonly overlay Miocene and also localized Pliocene deposits of Tertiary Basins (Krško, Kočevje and Kanižarica) and their surroundings. Plio-Quaternary layers consist mostly of reddish and brownish (locally also greyish) fine-grained siliciclastics and red soils. They may directly cover different Mesozoic formations in a non-uniform and up to $10 \mathrm{~km}$ wide lowland corridor between Ljubljana and Krško Basins (so-called covered karst of Dolenjska; Fig. 1). There, the Plio-Quaternary deposits have never been directly dated. Unclear stratigraphic interpretation is based only on the comparison with more or less similar deposits overlying Miocene or Pliocene sequences in both above mentioned Tertiary Basins.

The thickness of Neogene and Quaternary deposits may exceed 2,000 $\mathrm{m}$ in the central part of the Krško Basin syncline (Poljak \& Gosar 2001; Gosar et al. 2005). So-called Plio-Quaternary red and brown loam is only preserved in patches in other parts of the low karst of Dolenjska (Buser 1974; Markič 2009). While some researchers considered red clays to be a type of freshwater deposit (Buser 1974; Pleničar \& Premru 1977), the others described them as in situ or partly re-deposited weathering products on carbonate rocks (Gregorič 1969; Gams 2004; Rejšek et al. 2012).

The studied sediment section near Karteljevo village (Fig. 3) was located in a karst doline over a hundred meters wide and more than $10 \mathrm{~m}$ deep (Fig. 2). It was situated at 315-320 $\mathrm{m}$ a. s. 1 . on a wider elevated surface above the Bršljinski potok valley and some $160 \mathrm{~m}$ above the river Krka in the Krško Basin at highway profile No. 104. Hills above the levelled surface with elevations of about 500 $\mathrm{m}$ a. s. l. represent a catchment area of smaller perennial brooks flowing in the direction of the excavated doline. The doline was formed in the Late Jurassic massive coarsegrained bioclastic limestone (Otoničar et al. 2006). In the area, the Mesozoic carbonate successions are overlain by Upper Cretaceous to Early Eocene "flyshoid" sequences (Fig. 3). The area belongs to the easternmost part of extended Hrušica Nape (Placer 1999a) and represents part of the post-Miocene Sava compressional wedge close to its southwestern margin defined by the Stična Fault zone, a part of the Idrija tectonic zone (Placer 1999b).

\section{HRASTJE SEDIMENT SECTION}

The excavated sediment section on highway profile No. 104 (HP 104) in the bottom part of the doline was sampled in a thickness of $383 \mathrm{~cm}$ (Figs. 4, 6). It was composed principally of two parts: brownish yellow and grey which was which was separated by rubified transitional zone (Fig. 4a).
The upper part (Fig. 4c) consisted mostly of clays and silty clays with interbeds, bands and laminas of clayey silts and sands. Sediments were predominantly grey with transitions to greenish-grey, sometimes with brown and beige mottles and yellowish-brown laminas. Some laminas and bands were several millimetres to rarely 


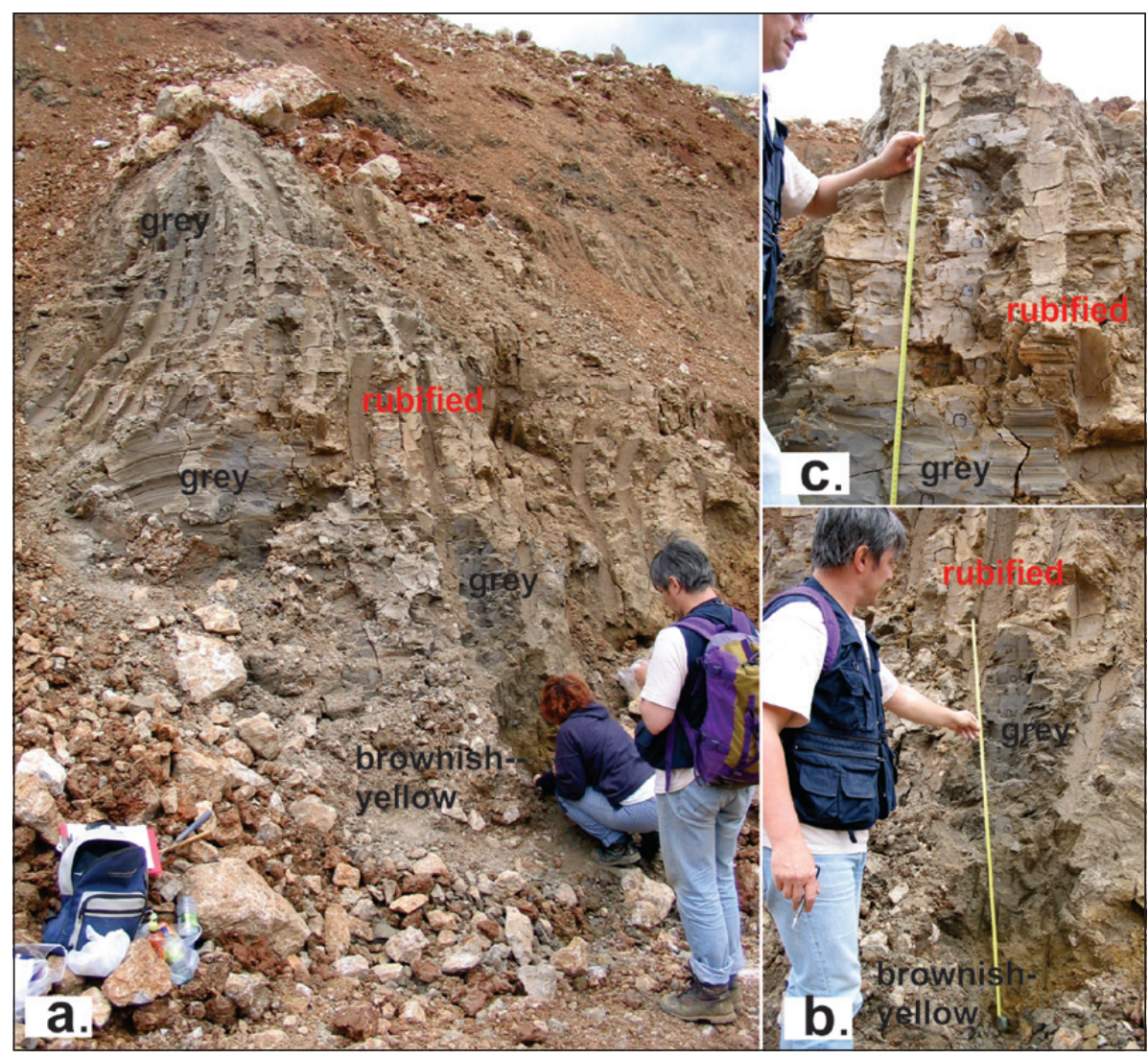

Fig. 4: Hrastje section at HP 104 covered by anthropogenic material from highway construction. Photo of $a$ - studied grey sediments; $b$ bottom part of the section (grey sediments overlie brownish-yellow sediments), with location of plastic cubes of paleomagnetic samples; $c$ - upper part of the section (grey sediments with rubified part). The lower part of the section (Fig. 4b) consisted of brownish-yellow clay to silt. Laminas were continuous or discontinuous and may show gradation and scour marks of millimetre scale. A mottled horizon between samples HL32 and HL33 contained plant remains and gastropods. Ferruginous coatings after root casts occured only close to the bottom of the section.

more than a centimetre thick and mostly yellowishbrown stained. The transitional zone between lower and upper grey sediments was rubified; that part of the section consisted of predominantly homogenous grey clay, with localizedreddish to brownish mottles and periodical intercalations of brownish-yellow silt and sandy silt (Fig. $4 a, c)$.

The sediments are not accessible anymore because the motorway road-cut is sealed with a concrete wall and a tunnel was built.

\section{MATERIAL AND METHODS}

Sediments were macroscopically described and sampled in the field. The methods for more detailed studies and analyses performed on the samples are listed methods below.

Paleomagnetic properties of 34 in situ oriented samples were analysed in the Department of Paleomagnetism, Czech Acad Sci, Inst Geol in Průhonice. The natural remanent magnetization (NRM) of sediments was measured using a JR-5A spinner magnetometer and the magnetic susceptibility (MS) of specimens was determined using a KLY-4 Kappabridge (Jelínek 1966, 1973). The alternating field demagnetization (AF) by LDA-3A demagnetizer gave consistently good results. All samples were subjected to detailed AF in 14 steps. Data were examined using vector endpoint or Zijderveld plots and M/
$\mathrm{M}_{\mathrm{n}}$ versus laboratory AF demagnetization fields. Individual components of magnetization were determined using principal component analysis (Kirschvink 1980) for each sample. The A-component is undoubtedly of viscous origin and can be demagnetized in the AF field ( $0-5$ up to $10 \mathrm{mT}$ ). The characteristic high-field component (ChHFC) is stable and can be demagnetized or isolated in the AF field (ca 10-80 up to100 mT). For detailed procedure descriptions see Zupan Hajna et al. (2008).

Standard zoopaleontological procedures were used to determine gastropod shells from the lower part of the section. The nomenclature and systematics follows Riedel (1983) and Welter-Schultes (2012). Paleoenvironmental characteristics follow Ložek $(1964,2000)$ and Alexandrowicz (1987). 
The MS U-series dating of gastropod shells failed due to technical problems with the counter in the laboratory at University of Bergen, Norway.

Samples for pollen analyses were prepared according to standard laboratory procedures (Fægri \& Iversen 1989).

The mineralogical composition was determined by powder X-ray diffraction (XRD). All powder patterns were collected with a Philips X'Pert APD diffrac- tometer (Department of Analytical Methods, Czech Acad Sci, Inst Geol in Praha) by standard procedures for randomly-oriented material, oriented specimens, glycolated specimens and the oriented samples heated to 400 ${ }^{\circ} \mathrm{C}$ under ambient atmosphere. For all samples, a region involving 060 reflection of clayey and micaceous minerals was scanned. All diffraction patterns were taken in the continuous scanning mode with scanning speed of $1^{\circ} \mathrm{min}^{-1}$ in the angular range $2-75^{\circ} 2 \Theta$.

\section{RESULTS}

\section{PALEOMAGNETIC AND PETROMAGNETIC RESULTS}

Sediments are characterized by the NRM intensities between 2.9 and $27 \mathrm{~mA} . \mathrm{m}^{-1}$ and the MS values from 101 to $494 \times 10^{-6}$ SI units. Only the bottom sample HL34 (reverse polarized) is characterized by high values for both of the NRM (1,973 mA.m $\left.{ }^{-1}\right)$ and MS (5,060 x 10-6 SI units). The mean direction and associated dispersion parameters of the Ch-HFC components with N polarity were calculated using Fisher statistics (Fisher 1953). The stereographic projection of the Ch-HFC with $\mathrm{N}$ polarity from is shown on Fig. 5 . The mean paleomagnetic directions of these components for the normal polarity are declination $(\mathrm{D})=4.4^{\circ}$, inclination $(\mathrm{I})=46.5^{\circ}$ (Tab. 1). Samples HL01, HL02, HL09, HL31 to HL33 were not used for the multi-component analysis as MAD values were higher than 6 (i.e., than the recommended value). Paleomagnetic directions for the sample with reverse polarity are: $\mathrm{D}=212^{\circ}, \mathrm{I}=-40^{\circ}$. The systematic acquisition of paleomagnetic data allowed the construction of a detailed magnetostratigraphic section (Fig. 6).

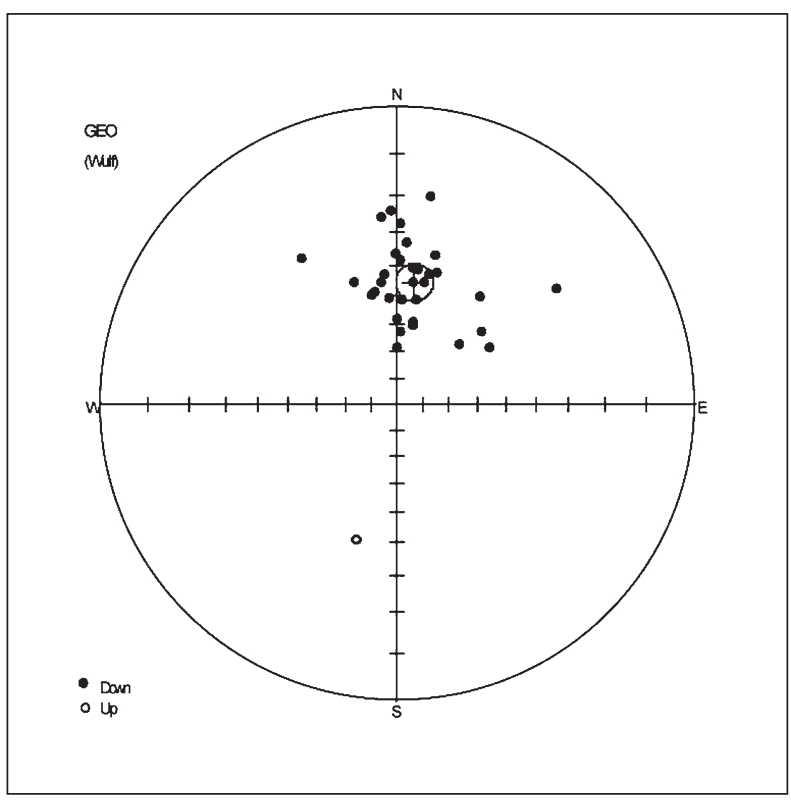

Fig. 5: Mean directions of the ChRM components with normal (full) and reverse (open) paleomagnetic polarity for the sample $H L$ 34. Stereographic projection, full circles represent projection onto the lower hemisphere. The mean directions calculated according to Fisher (1953) are marked by a small cross across a circle; the confidence circle at the $95 \%$ probability level is circumscribed about the mean direction.

Tab. 1: Mean paleomagnetic directions of samples (recalculated from Zupan Hajna et al. 2008, p. 202). Explanations: $N$ - normal polarity; $D, I$ - declination and inclination of the remanent magnetization after dip correction; $\alpha_{95}$ - semi-vertical angle of the cone of confidence calculated according to Fischer (1953) at the 95\% probability level; $k$-precision parameter; $n$ - number of analyzed samples.

\begin{tabular}{|c|c|c|c|c|c|}
\hline \multirow[t]{2}{*}{ Polarity } & \multicolumn{2}{|c|}{$\begin{array}{c}\text { Mean paleomagnetic } \\
\text { Directions }\end{array}$} & \multirow{2}{*}{$\begin{array}{l}\alpha 95 \\
{[0]}\end{array}$} & \multirow[t]{2}{*}{$\mathbf{k}$} & \multirow[t]{2}{*}{$n$} \\
\hline & $\mathrm{D}$ [o] & I [o] & & & \\
\hline $\mathrm{N}$ & 4.4 & 46.5 & 4.7 & 36.0 & 27 \\
\hline
\end{tabular}




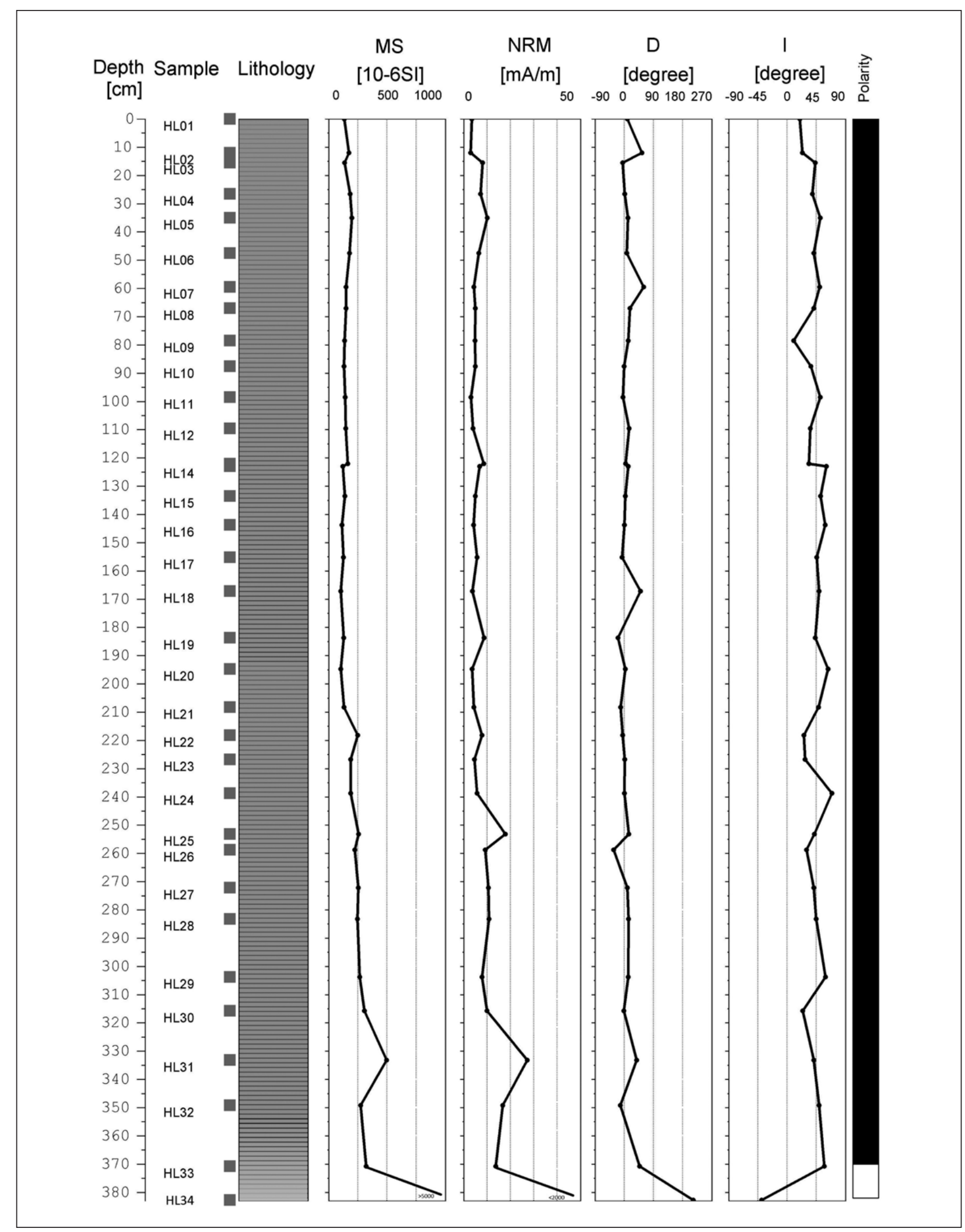

Fig. 6: Basic magnetic and paleomagnetic properties of Hrastje section (same as HP 104 on Fig. 3). Black - N polarity, white - reverse polarity, MS - the MS of samples in natural state, NRM - the modulus of the NRM, D - declination, I - inclination (modified from Zupan Hajna et al. 2008, p. 203). 


\section{GASTROPODS}

Few gastropod shells were found between samples HL32 and HL33 (Fig. 7), i.e., from the lower part of the doline fill. Two shells were partly broken in apertural segments. Only 3 specimens were collected directly from the section by macroscopic separation.

The determination confirmed the following taxa and species (Fig. 7):

- Specimen 1 - Aegopinella cf. minor (Stabile 1864), family Zonitidae (Fig. 7/1-5), adult individual with typically developed compressed round shell of 4.5 whorls. Conchological features indicate species be- longing to Aegopinella minor. The species of genus Aegopinella can be very similar, especially species $A e-$ gopinella minor and A. nitens. Accurate determination also requires a genital autopsy, which was not possible in this case. Our individual of Aegopinella belongs to A. minor with very high probability.

- Specimen 2 - Vallonia pulchella (O. F. Müller, 1774), family Vallonidae (Fig. 7/6-10), a subadult individual without developed peristome, but typically compressed round shell of 3 whorls.

- Specimen 3 - Hygromiidae gen. et sp. indet. (Fig. 7/11-15), a subadult individual with a fragmented

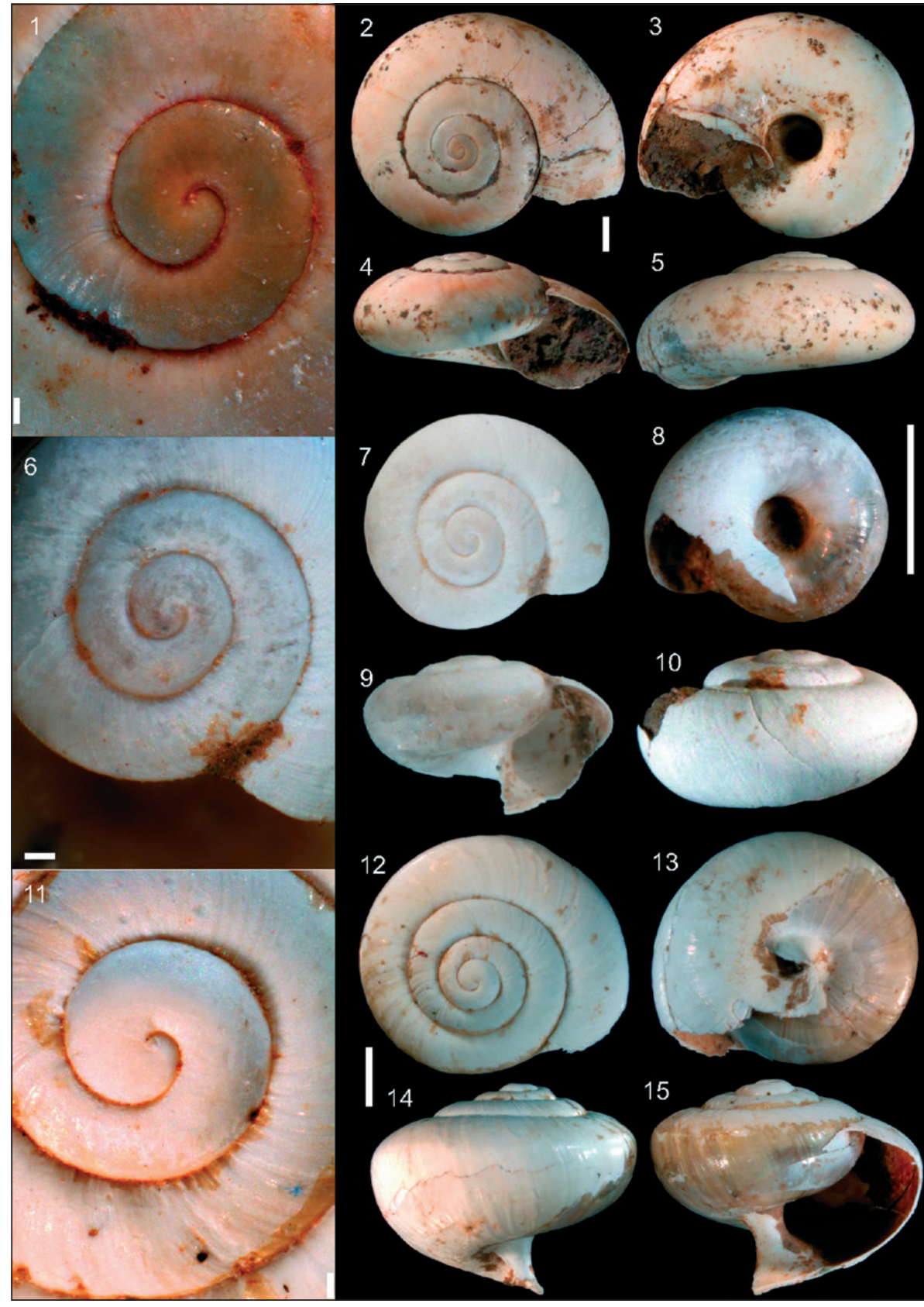

Fig. 7: Gastropod photos from sample HL32 and HL33in different positions. 1-5 Aegopinella cf. minor (Stabile 1864), view: 1 - detailed apical, 2 - apical, 3 - umbilical, 4 - apertural, 5 - abapertural; 6-10 Vallonia pulchella (O. F. Müller, 1774), view: 6 - detailed apical, 7 apical, 8 - umbilical, 9 - apertural, 10 - abapertural; 11-15 Hygromiidae gen. et sp. indet., view: $11-d e-$ tailed apical, 12 - apical, 13 - umbilical, 14 - lateral, 15 - apertural (Photo: Oleg Mandić). Scale bars: $0.1 \mathrm{~mm}=1,6,11 ; 1 \mathrm{~mm}=2-5,7-$ 10,12-15. 
shell in the apertural part. The shell has 4.5 whorls which indicate a subadult individual in this case. The shell surface has no preserved special determination characteristics to allow more generic or even species classification. On the basis of shell measurement, this individual is a medium-sized member of family Hygromiidae which is one of the richest European gastropod families with a high number of species.

\section{PALYNOLOGY}

We analysed 11 pollen samples (Tab. 2). Four samples (HL24, HL26-HL29, HL32-HL34 and HL33-HL34 were taken from the paleomagnetic section at the highway profile No. 104 (Fig. 3). Five samples, roughly stratigraphically parallel to the lower part of paleomagnetic section, were sampled for comparison from the same filled doline at nearby highway profile No. 105 (Fig. 3).
One additional sample was taken from the lower part of the filled doline containing the paleomagnetic section. Another sample represents wooden particles collected randomly in the lower part of the same doline. These additional samples were collected as sources of the additional information when the paleomagnetic section (No. 104) was already destroyed.

Each sample related to the paleomagnetic section comprises composite material taken between quoted paleomagnetic samples. Although we examined numerous microscopic slides, usually not more than a few to a few tens of pollen grains occurred per slide, with the exceptions of the sample HL26-29 with almost 400 grains, and partly also HL24. Due to the generally scarce pollen content, the results are presented in table (Tab. 2) are shown as numerical values of pollen grains and not as composite palynological graphs.

Tab. 2: Palynospectra of the section Hrastje or profile HP104 and HP105

\begin{tabular}{|c|c|c|c|c|c|c|c|c|c|c|c|}
\hline \multirow{3}{*}{$\begin{array}{l}\text { Highway section } \\
\text { Sample No. }\end{array}$} & \multicolumn{11}{|c|}{ Filled karst doline } \\
\hline & \multirow[b]{2}{*}{ wood rem. } & \multirow[b]{2}{*}{ lower pt. } & \multicolumn{5}{|c|}{ No. 105} & \multicolumn{4}{|c|}{ No. 104} \\
\hline & & & $8 b$ & $8 a$ & 7 & 3 & 1 & $34-33$ & 34-32 & $29-26$ & 24 \\
\hline Pinus & 3 & & 1 & & & & 1 & & & 6 & \\
\hline Picea & & & & & & & & & & 19 & 5 \\
\hline Abies & 1 & & & & & & & & & 28 & 2 \\
\hline Juniperus & 1 & & & & & & & & & 1 & \\
\hline Taxus & & & & & & & & & & 1 & \\
\hline Ephedra & 1 & & & & & & & & & 1 & \\
\hline Betula & 3 & & 3 & 3 & & & & & & 43 & 2 \\
\hline Alnus & 19 & & 18 & 2 & & 1 & 1 & & 5 & 41 & 11 \\
\hline Corylus & & & & & & & & & & 33 & 10 \\
\hline Carpinus & & & & & & & & & & 17 & 1 \\
\hline Fagus & & & & $1 ?$ & & & & & wood & 83 & 1 \\
\hline Carya & & & & & & & & & & & 1 \\
\hline Ulmus & & & 1 & & & & & & & 1 & 1 \\
\hline Quercus & & & & & & & & & & 3 & 3 \\
\hline Tilia & 1 & & & & & & & & & 1 & \\
\hline Castanea & & & & & & & & & & 1 & \\
\hline Juglans & & & & & & & & & & 4 & \\
\hline Artemisia & & & & 1 & & & & & & & \\
\hline Gramineae & & & 1 & & & & & & & 12 & 1 \\
\hline Umbeliferae & 1 & & 2 & & & & & & 1 & 6 & 3 \\
\hline Chenopodiaceae & & & & & & & & & & 2 & \\
\hline Caryophyllaceae & & & & & & & & & & 3 & \\
\hline Compositae-tub. & 1 & & 7 & & & & 1 & & 1 & 16 & 4 \\
\hline Compositae-lig. & 2 & & 1 & 1 & & & & & & 5 & 1 \\
\hline Plantago & & & & & & & & & & 4 & \\
\hline Cyperaceae & 1 & & & & & & & & & 2 & 2 \\
\hline Myriophyllum & & & & & & & & & & 1 & \\
\hline Sporae monol. & 32 & 11 & 13 & & & 9 & 1 & 13 & 74 & 27 & 13 \\
\hline Sporae tril. & 5 & 1 & 5 & 2 & & & 2 & & & 17 & 3 \\
\hline Selagimella & & & 1 & & & & & & & & \\
\hline
\end{tabular}


Among pollen grains, tree species (AP) predominated, while pollen grains of herbaceous vegetation (NAP) are less common. Abies pollen grains prevail among the coniferous vegetation (ca $8.3 \%$ ); Picea is less abundant (ca $5.7 \%$ ), while Pinus is much less abundant. Betula (ca $12.8 \%$ ), Alnus (ca 12.2\%), Corylus (ca 9.8 \%) and Carpinus (ca $5 \%$ ) prevail among deciduous vegetation, while Quercetum mixtum (Quercus, Tilia, Ulmus) was scarcely present. By contrast, Fagus pollens are very abundant (ca $24.8 \%$ ). Pollen grains of Castanea, Juglans, Taxus and water plant Myriophyllum occurred sporadically. Remnants of wood with anatomical characteristics of beech (Fagus) were identified in the lower part of the section (sample HL32-34).

\section{MINERALOGY}

Sediment samples (HL08, HL19, HL23 and HL33) were collected from the Hrastje section (the paleomagnetic section) at highway profile No. 104 (Fig. 3). Reddish and grey clays (SLO 36 to SLO 38) were sampled from the same depression (at highway profile No. 105), but at the edge of the grey sediments towards the doline slope. A sample of red soil (SLO 7) was taken from highway profile No. 135 about one $\mathrm{km}$ from the studied profile. Two comparative samples (SLO 35 and SLO 39) were taken from two sites at highway construction some four kilometres away from the studied doline at highway profile No. 279. The mineralogical composition was inferred from patterns acquired from randomly-oriented, oriented, glycolated and heated specimens. Major and minor constituents of each sample are summarized in Tab. 3.

Quartz with muscovite and chlorite dominated in almost all analysed samples (HL08, HL19, HL23, HL33) from the studied Hrastje section (profile No. 104); in all of those samples feldspars were also present. Prevailing chlorite with some goethite, muscovite and chlorite admixture was detected in red clay (SLO 36, profile No. 105). Calcite was associated with traces of randomlyinterstratified structures of chlorite-muscovite type in green clay from dolomite (SLO 35, profile No. 279 on Fig 3). Kaolinite and montmorillonite prevailed with hematite in traces in red soil sample (SLO 7).

Mineralogical composition of grey laminated sediments which were slightly coloured were more or less equal (with differing quantities of quartz, chlorite, muscovite, feldspar); only the pigmentation varied vertically and horizontally along the section. In red soil, the mineralogical composition was different, since kaolinite and quartz predominated.

Tab. 3: Sample lithology and results of XRD mineral identification (major phases in bold; completed from Bosák et al. 2006) of samples from highway profiles HP104, HP105, HP135 and HP279. Explanation: ${ }^{*}$ as well as scans over region corresponding to 060 reflection of clayey and micaceous minerals; bold - dominating mineral; profile - number of highway profile; pink coloured cells - red soil sample.

\begin{tabular}{|c|c|c|c|c|}
\hline \multirow{3}{*}{$\begin{array}{l}\text { Sample } \\
\text { Number ( } \\
\mathrm{HL}=\text { paleomagnetic } \\
\text { sample) }\end{array}$} & \multirow{3}{*}{ Lithology } & \multicolumn{3}{|c|}{ Mineralogical composition } \\
\hline & & \multirow{2}{*}{ randomly oriented samples } & \multicolumn{2}{|c|}{ oriented, glycolated, and heated samples* } \\
\hline & & & mineralogical composition & interstratified structures \\
\hline $\begin{array}{l}\text { HL } 8 \\
\text { profile } 104\end{array}$ & $\begin{array}{l}\text { grey clay with } \\
\text { brown and beige } \\
\text { mottles }\end{array}$ & $\begin{array}{l}\text { quartz, muscovite, chlorite, } \\
\text { feldspar }\end{array}$ & $\begin{array}{l}\text { quartz, muscovite, } \\
\text { chlorite, feldspar }\end{array}$ & chlorite-muscovite \\
\hline $\begin{array}{l}\text { HL19 } \\
\text { profile } 104\end{array}$ & brown sandy silt & $\begin{array}{l}\text { quartz, muscovite, chlorite, } \\
\text { feldspar }\end{array}$ & quartz, muscovite, chlorite & chlorite-muscovite \\
\hline $\begin{array}{l}\mathrm{HL} 23 \\
\text { profile } 104\end{array}$ & grey clay & $\begin{array}{l}\text { quartz, muscovite, chlorite, } \\
\text { feldspar }\end{array}$ & $\begin{array}{l}\text { quartz, muscovite, } \\
\text { chlorite, feldspar }\end{array}$ & chlorite-muscovite \\
\hline $\begin{array}{l}\text { HL } 33 \\
\text { profile } 104\end{array}$ & $\begin{array}{l}\text { brown-yellow silt } \\
\text { with orange spots }\end{array}$ & $\begin{array}{l}\text { quartz, muscovite, chlorite, } \\
\text { feldspar }\end{array}$ & quartz, muscovite, chlorite & chlorite-muscovite \\
\hline $\begin{array}{l}\text { SLO } 36 \\
\text { profile } 105\end{array}$ & reddish clay & chlorite, goethite & muscovite, chlorite & none \\
\hline $\begin{array}{l}\text { SLO } 37 \\
\text { profile } 105\end{array}$ & greyish-brown clay & $\begin{array}{l}\text { quartz, muscovite, chlorite, } \\
\text { feldspar }\end{array}$ & quartz, muscovite, chlorite & chlorite-muscovite \\
\hline $\begin{array}{l}\text { SLO } 38 \\
\text { profile } 105\end{array}$ & $\begin{array}{l}\text { grey silt with white } \\
\text { spots }\end{array}$ & $\begin{array}{l}\text { quartz, muscovite, chlorite, } \\
\text { calcite, feldspar }\end{array}$ & quartz, muscovite, chlorite & chlorite-muscovite \\
\hline $\begin{array}{l}\text { SLO } 7 \\
\text { profile } 135\end{array}$ & red soil & kaolinite, montmorillonite & muscovite, illite, hematite & $\begin{array}{l}\text { montmorillonite- } \\
\text { muscovite }\end{array}$ \\
\hline $\begin{array}{l}\text { SLO } 39 \\
\text { profile } 279\end{array}$ & $\begin{array}{l}\text { laminated brown } \\
\text { clay with thin } \\
\text { yellow laminas }\end{array}$ & $\begin{array}{l}\text { quartz, calcite, muscovite, } \\
\text { chlorite, feldspar }\end{array}$ & quartz, muscovite, chlorite & chlorite-muscovite \\
\hline $\begin{array}{l}\text { SLO } 35 \\
\text { profile } 279\end{array}$ & $\begin{array}{l}\text { green clay in sandy } \\
\text { dolomite }\end{array}$ & calcite, dolomite, muscovite & $\begin{array}{l}\text { quartz, muscovite, calcite, } \\
\text { ?kaolinite, ?illite }\end{array}$ & none \\
\hline
\end{tabular}




\section{DISCUSSION AND PALEOENVIRONMENTAL RESULTS}

The studied site and sedimentary successions in the Krško Basin cannot be directly correlated although they are geographically situated quite close to each other. The Krško Basin is a rather large tectonic depression with the character of a still active compressing syncline filled by over 2000 m of Neogene and Quaternary depositional sequence (Poljak \& Gosar 2001; Gosar et al. 2005) while the studied site represents a rather limited depositional area on karst relief. The Quaternary succession of the Krško Basin is built of interglacial, mainly fine-grained clastics of local alluvial input. They are disturbed by coarsegrained clastics of the river Sava, representing peaks of glacial periods and mainly deglaciation pulses (Verbič 2004). The wider surroundings of the Krško Basin, including the studied site, have been tectonically very active throughout the whole Quaternary (e.g., Verbič 2004; Vrabec \& Fodor 2006). For example, the vertical component of the activity of the Artiče Fault is up to $15 \mathrm{~m}$ for the last $150 \mathrm{ka}$ and up to $240 \mathrm{~m}$ for the last 1 to $2 \mathrm{Ma}$ (Verbič 2004).

\section{PALEOMAGNETISM AND MAGNETOSTRATIGRAPHY}

Determined principal magnetic polarity directions were compared with the standard geomagnetic polarity time scale (GPTS; Cande \& Kent 1995). Except for the last sample with reverse polarization at the bottom of the sampled section, all other samples show normal polarization. The mean paleomagnetic direction, derived from well-grouped vectors representing normal polarity, gave the evidence for probably clockwise rotation. If we consider the declination of $2.6^{\circ}$ (at the time of sampling), then a clockwise rotation value is $1.8^{\circ} \pm 4.7^{\circ}$. Precise evaluation of paleomagnetic parameters indicates the geomagnetic excursion is unambiguous; we assume it is Blake excursion within the Brunhes chron.

The character of D and I corresponds to zero Late Pleistocene and Holocene surface tilt of terraces within nearby Krško Basin. Verbič $(2004,2005)$ described diminishing inclination of so-called Plio-Quaternary to Middle Pleistocene terrace surfaces in the direction of the pre-Quaternary Krško syncline axis. Geodetic observations indicate ongoing folding within the Krško Basin (Poljak et al. 2010), which is not the case of the Hrastje section according to paleomagnetic parameters. Bavec et al. (2011) noticed these geodetic observations are without exception within the measurement error.

Higher MS and NRM values in samples HL22, HL25 to HL28 and HL30 to HL32 above the paleosol horizon correspond to later rubification processes (reddish- to yellowish-brown lamination, mottling and staining). The
MS and NRM values in samples below the protosol horizon are higher; in the reverse polarized sample HL34 for two orders higher than in samples above paleosol (NRM: 1,973 mA.m ${ }^{-1}$; MS: 5,060 x10-6 SI units).

Based on D and I values, we assume that there are not sufficiently centred paleosecular variations and deposition velocity might be relatively very high.

\section{GASTROPODS}

The terrestrial snail specimens record informative value about different paleoenvironmental conditions. Vallonia pulchella is a typical member of malacocoenoses of xerotermic habitats. This species prefers open ground habitats and avoids closed forests; thus the species is a typical heliophilous element. The occurrence of this species indicates the presence of some type of open ground habitat, probably in the form of small patches. Glacial environments are excluded, owing to type sediment in which the shell was preserved. Aegopinella cf. minor is a species of warm light forests, but not humid environments. It belongs to ecological group 2W(s) (after Ložek 1964, 2000; Alexandrowicz 1987), which associates species with an affinity for sparse forests and semidry woodland with semidry habitats. The species is a typical representative of the warm phases of Quaternary climatic cycle. The specimen determined as a taxon of family Hygromiidae has no outstanding indicator value. On the basis of shell shape, we could exclude some taxa of xerotermophilous elements such as genus Xerolenta, Helicella, Helicopsis, and Monacha. The shell shape appears to be similar to those of some species of genus Monachoides or Hygromia, but we lack specific determination character on the shell surface.

\section{PALYNOLOGY}

The lower part of the section ("lower part" and HL33-34; Tab. 2) contains only Sporae monol., rare Sporae tril. and Fagus wood. The material of sample HL34-32 represents a mixture of material from above and below the paleosurface with protosol.

Relatively poor palynospectra in the upper part of the section (samples HL24 and HL26-29; Tab. 2) suggest that during the sedimentation, the dominant cover of the landscape surrounding the investigated section was most likely riparian forest of temperate climatic zone. Several genera present (i.e., Myriophyllum and Cyperaeceae) indicate a quite humid environment (wetlands and ponds on periodically flooded plains). The relative scarcity of palynospectra (except one cumulative sample) could also result from quite rapid deposition of the grey laminated sediments, which means that the chance for pollen to be 
trapped in our sediment decreases with the species abundance. It does not mean that species/genera not recorded in our spectra did not occur in original plant assemblages. The other possibility is that the lake had an outflow and flowing water transported pollen grains out of the depocenter.

The chronological determination is rather uncertain as pollen analyses cover only a part of the sedimentary sequence. However, the determined vegetation could be placed in the Late Pleistocene with a high degree of certainty. Unfortunately, sections with Late Pleistocene vegetation are scarce in Slovenia. Two cores over $100 \mathrm{~m}$ deep were palynologically analyzed and determined in the Ljubljana Moor (Šercelj 1965, 1966). There, the interglacial (Eemian, i.e., MIS 5e) as well as interstadial (MIS 5 c of Last Glacial) determined vegetation is comparable with our site. The high percentage of beech pollen in our samples indicates rather interglacial conditions. Although beech was already present in the Ljubljana Moore at that time, it was not as abundant as in our samples. However, Pinus was more common in the Ljubljana Moore but its curve in pollen diagram is oscillates. Pollen of Taxus, Carya and Tsuga is still present sporadically, while in all our samples only one grain of Taxus and one of Carya have been found. Elements of Tegelen-type of flora gradually disappeared from the Pleistocene vegetation, although south of Alps it persisted longer than in the regions north of them, even into the Late Weichselian (Šercelj 1965).

Pollen from sample HL26-29 are comparable with certain segments of the pollen diagrams from the Mondsee (near Salzburg City, Austria, northern Alpine foothills; Drescher-Schneider 2000) correlated with MIS 5c (see Pini et al. 2009), but elements of Tegelen-type of flora as well as beech pollen are missing there. In contrast, the Eemian interglacial vegetation from Central Italy comparable with our samples still contains abundant elements of the Tegelen-type flora, i.e., Pterocarya and Zelkova, as well as beech pollen (Follieri \& Magri 2001). According to comparison with Zuzano Decimo core (plain of Friuli, NE Italy, close to Dinaric Karst) where pollen of thermophilous trees and shrubs (deciduous Quercus, Corylus, Ulmus, Tilia, Carpinus) dominates while the frequency of Fagus pollen is low (Pini et al. 2009), we can also correlate Hrastje section with MIS 5e. They stated that the continuous record of Fagus, although with low percentage values, is unprecedented in classical Eemian equivalents in the Alpine region. Magri et al. (2006) and Pini et al. (2009) connected post-Eemian Fagus expansion at many European sites to MIS 5c (at ca 105-95 ka) when becoming quite abundant in Italian and Balkan peninsulas, and also across the Alps.

The closest dated clayey material somewhat similar to the studied section is documented from a clay pit at the brick factory few kilometres to the west from Novo mesto. There, the Cromerian interglacial and one of the Menapian interstadials were reported from the lower part of the section where the Tegelen-type of vegetation was determined with a remark that even older Pleistocene ages are not excluded (Šercelj 1961a, b, 1963). The upper horizon of the pit includes pollen typical for glacial periods, most probably from the last Weichselian colder stage (Šercelj 1963).

\section{MINERALOGICAL COMPOSITION AND ITS ORIGIN}

Clay minerals in soils and clastic (e.g., alluvial) sediments represent products of dynamic systems that are strongly affected by time-influenced changes of environment when they originated (deposition, weathering, pedogenesis). Main components of studied sediments are not representative of clay minerals or iron oxides related to intensive weathering, i.e., sediments were not subjected to intensive weathering/pedogenesis before and especially after the deposition; the sediments are not too mature (plagioclases and muscovite are still present). The mineralogical composition of nearly all samples is similar in general with the exception of the mineralogical composition of red soil sample.

In a paleogeographic sense, the wider surroundings of the studied area belong to the eastern marginal parts of Adriatic carbonate platform (Jurassic and Cretaceous) and its slope towards the Slovenian Basin. The area was uplifted, subaerially exposed, tectonically dissected, denuded, and karstified after the Paleogene. It is evident that the studied clayey material was deposited over already well-expressed karst relief (Fig. 2), developed after the erosion of Cretaceous to Early Eocene "flyschoid" deposits overlying older carbonate sequences (see Crnjaković 1981). Nevertheless, the erosion relics of "flyschoid" deposits still occur in the area; the closest ones are just a few hundred meters from the studied site (Otoničar et al. 2006; Fig. 3).

Plagioclases do not represent insoluble remains of limestone as their amounts were not determined in respective weathering products of Cretaceous and Jurassic limestones of the Dolenjska region. The plagioclase source can be found in re-deposited weathering residua of non-carbonate rocks or some other type of sedimentary cover (Habič 1992; Zupan Hajna 1992). Patches of similar reddish-brown, reddish and yellowish loamy to sandy deposits were also found west from the studied section in the Suha Krajina but in slightly higher altitudes.

The origin of grey alluvial, lacustrine or/and paludal laminated sediments can be specified from the mineralogical composition only conditionally. We can 
exclude the in situ weathering of local carbonate rocks, except in the case of sample SLO 35 (weathered dolomite with green clay) which is not directly connected with the studied site. The main source of grey sediment can be related to non-carbonate rocks from the vicinity, i.e., Cretaceous to Early Eocene "flyschoid" deposits or older alluvial sediments from various locations on the Dolenjska Karst (Zupan Hajna 1992). We suggest that parent material, composed of Late Cretaceous flyschoid marls, clayey limestones and calcarenites with different amount of clayey materials and quartz grains, was eroded from the upper parts of nearby hills (Fig. 3) and transported down slopes to a karstified surface already covered by red soils.

The transitions from grey and brownish-grey (coloured by goethite pigment) through the mottled horizon to reddish-brown sediments (coloured by hematite pigment) indicates the effects of rubification. It is influenced by meteoric waters percolating through deposits after their deposition and reflects the redox potential change (from the reduction to oxidation environment; Mihevc \& Zupan Hajna 1996). The rubification penetrates into the sediment and forms red clay coatings. Goethite (sample SLO 36) and hematite apparently represent just the pigment (coating over other mineral particles) in amount so low that they cannot be detected even in traces in XRD records of reddish samples. Heavy mineral assemblages in trace amounts cannot be detected by the XRD as well.
The reddish clay (SLO 36, profile 105) and grey laminated sediment of the Hrastje section (profile 104) differ in mineralogical composition from red soil material (sample SLO 7, profile 135). The red soil contains kaolinite and montmorillonite, interstratified structures of illite and montmorillonite-muscovite type of clay minerals as the main components, which indicate strong or long-lasting weathering, but no quartz, chlorite and feldspar. Red soil (SLO 7) can be classified as typical red soils (i.e., terra rossa) which are known along Dinaric Karst and in the whole Mediterranean region as well (Fedoroff \& Courty 2014). The literature does not provide much information about the duration of the rubification-illuviation phase of red Mediterranean soils (RMSs; see Fedoroff \& Courty 2014). Based on the high number of microlamination and the thickness of the clay coatings and their abundance in the RMSs, the rubification-illuviation process can be very fast, from 100 years to a few thousand years and it is believed that it is related to interglacials (e.g., Carboni et al. 2006; Zembo 2010), especially their wet phases (Badía et al. 2009; Wagner et al. 2012).

Different mineralogical compositions of red soil and grey laminated sediments which were partly rubified can easily indicate that grey sediments (1) are less weathered; (2) they have other source material provenience than red soils, and (3) they are younger than underlying red soil. In addition, the mineralogical study indicates that the source material of grey laminated sediments may derive

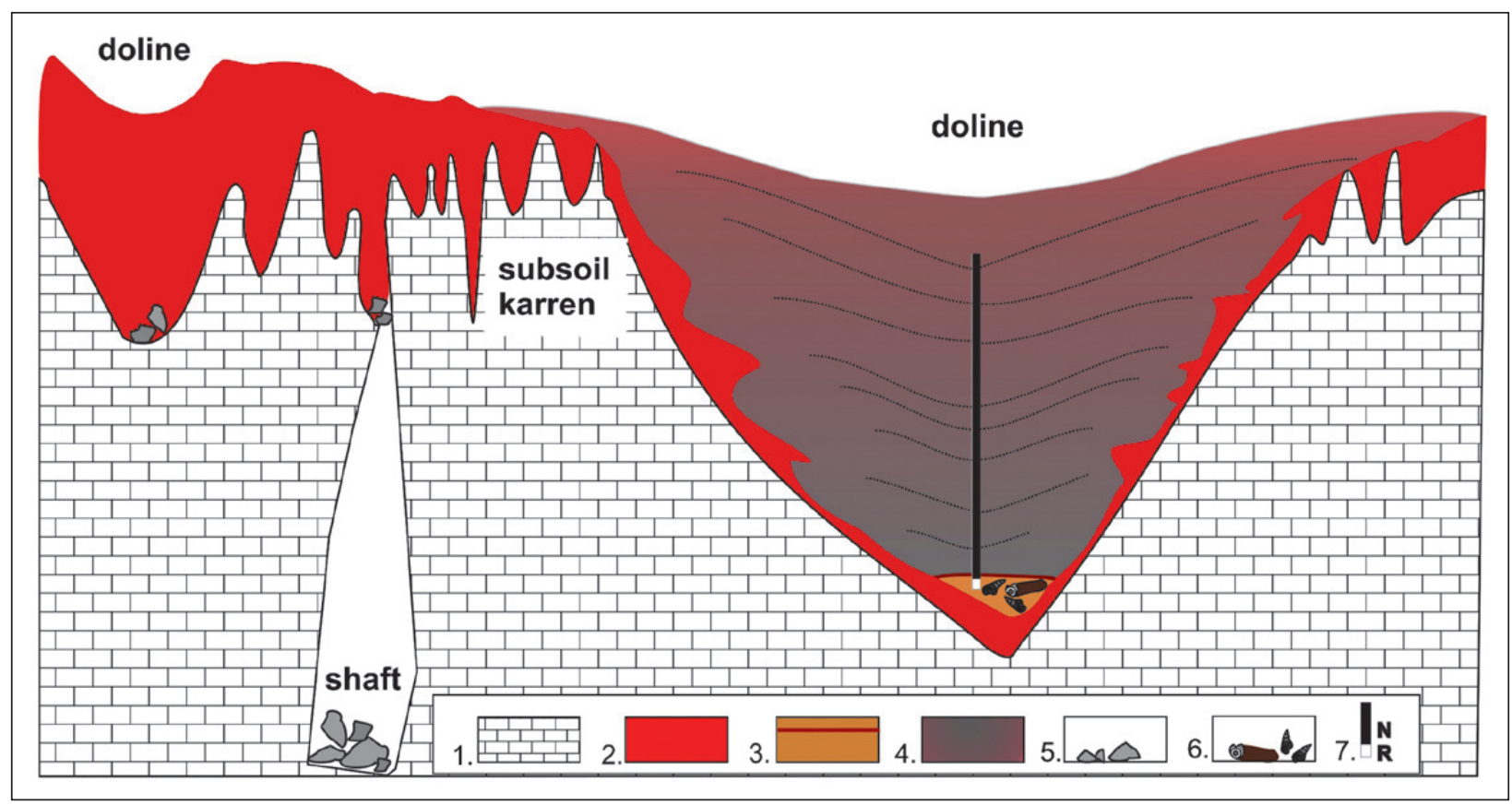

Fig. 8: Schematic cross section of doline filled by red soil and lacustrine laminated sediments. Legend: 1 - Karstified Jurassic limestone; 2 - Well-developed red soil (terra rossa); 3 - Brownish-yellow clay to silt with plant remains and ferrugineous coatings; 4 - Partly rubified grey sediment containing mostly quartz, feldspars and chlorite; 5 - Rock debris; 6 - Wood, plants and gastropods; 7 - Studied section with magnetic polarity: black - normal polarity, white - reversal polarity. 
from eroded nearby non-carbonate sedimentary rocks. The relation of grey laminated sediments and red soil and the karstified carbonate bedrock is shown on the schematic model in Fig. 8.

It follows that the grey laminated sediments cannot represent the source material of Dolenjska red soils (i.e., terra rossa). Clear vertical and lateral colour changes from the central part towards marginal parts of studied sediments resulted from post-depositional changes, i.e., rubification. More distinct reddish- to yellowish-brown laminas in samples HL14 to HL24 indicate the transport of eroded and re-worked red-coloured sediments into grey sediments from nearby areas or in situ rubification on the lake floor, which correspond to higher MS a NRM values. Ochre to reddish staining and mottling is the result of oxidation of iron minerals and formation of goethite and hematite pigments by the rubification process which is also responsible for increased MS a NRM values. Oxidizing meteoric waters have percolated more easily into sediments along bedrock/sediment contacts, than through impermeable clayey deposits in the central part of the doline, where overlaying strata sealed the doline fill and protected the central part of doline from the oxidation. Mostly sediments at the top of doline fill and in the border zone along the walls of depression where meteoric water could reach them were partly rubified.

Palynospectra with quite abundant Fagus indicate that the dominant landscape cover during sediment deposition was most likely forest with wetlands and ponds on periodically flooded plains. The Fagus abundance might indicate that the area was a part of the Eemian refuge (Magri et al. 2006; Brus 2010) at that time. The scarce palynospectra and not stabilized secular variation in grey laminated sediments can indicate a quite rapid depositional rate of grey laminated sediments. The doline represented a trap for siliciclastic material with a highly reduction environment at the bottom full of vegetation fragments and pieces. Yellowish- and reddish-brown mottling and staining mostly resulted from post-depositional rubification processes responsible for increased
MS and NRM values and probably represent inverted pseudogley.

Paleosol horizon between samples HL32 and HL33 with plant remains, gastropods, and ferruginous coatings after root casts represents the important paleoenvironmental and stratigraphic boundary (unconformity). The sediment is clayey silt, yellowish-brown in colour. Gastropod assemblages in the paleosol indicate the presence of open ground habitats, probably in the form of small patches within warm sparse forests and semidry woodland. The species are typical representatives of Quaternary warm phases. Palynological assemblages below the paleosol are highly impoverished, containing only limited numbers of Sporae monol., rare Sporae tril. and fragments of Fagus wood. The lowest paleomagnetic sample shows reverse polarity of the magnetic field and in order higher MS and NRM values.

If we accept the correlation of Hrastje palynospectra with those of the Mondsee site (Austria) and their radiometric dating (Pini et al. 2009), then the grey sediments were deposited during MIS 5c (ca 105 to $85 \mathrm{ka} \mathrm{BP}$; Railsback et al. 2015) and sediments below the paleosol horizon with reverse polarization of the last sample can correspond to the Blake excursion and consequently relates to MIS 5e.

The Blake excursion was identified by Smith \& Foster (1969) for the first time. The age of the Blake event has been dated by different methods of numerical dating mostly from ca 120 to ca $111 \mathrm{ka}$ (e.g., $111.8 \pm 1$ to $117.1 \pm 1.2$ ka: Zhu et al. 1994 from Chinese loess; 114.47 to 119.97 ka: Fang et al. 1997 from Chinese loess or $112.0 \pm 1.9$ to $116.5 \pm 0.7 \mathrm{ka}$ : Osete et al. 2012 in stalagmite). Dates according to applied dating methods (Singer 2014) vary from 130-124 ka (Bourne et al. 2010) up to 114-108 ka BP (Smith \& Foster 1969) with event duration of ca 4 to $6 \mathrm{ka}$ (according to different sources). The excursion consequently relates to MIS $5 \mathrm{e}$, its late part, or to the vicinity of MIS 5e/5d boundary (cf. Singer 2014; Railsback et al. 2015). Its bipartite composition (Singer 2014) was not detected in our section.

\section{CONCLUSIONS}

The fill of a large karst depression (doline) was excavated during the construction of the Slovene highway No. A2 at section Hrastje - Lešnica in the Dolenjska region. The fill represents the youngest sedimentation of the site and overlies red soils (i.e., terra rossa).

From the base up, the fill consists of: (1) brownishyellow clays to silts locally with a few plant remains, fer- rugineous coatings after root casts and gastropods (paleosol horizon) contain chlorite, muscovite and feldspars are present in the bottom part. The mineralogical composition shows no difference regarding upper part of the section except that there is more reddish stained and that was already partly changed due to pedogenesis (start of paleosoil formation). Strongly impoverished malacocoe- 
nosis indicates only general paleoenvironmental characteristics, which are consistent with a warm phase of one of Quaternary climatic cycles with developed light, semiopen forest with patches of open ground habitats, i.e., paleoenvironmentally different conditions from those present during deposition of overlying grey sediments. The only paleomagnetic sample show reverse magnetization. The precise evaluation of paleomagnetic parameters indicates the geomagnetic excursion is unambiguous. We assume it is the Blake excursion (ca. 120-112 ka; MIS 5e) rather than Brunhes/Matuyama boundary (0.78 Ma; MIS 19).

(2) Lacustrine (palustrine) laminated grey to greenish grey deposits dominated by quartz, muscovite, chlorite and feldspar with randomly interstratified structures of chlorite-muscovite type. The sediment is almost unweathered (suggested by the content of feldspars, muscovite and chlorite) but partly rubified at the contact with percolating water and older red soils. They were deposited were deposited in a colder climate (low MS and NRM values) with reduction conditions at the lake bottom full of decomposing organic matter.

The mineralogical composition of laminated grey sediments and underlying older terra rossa soils indicates that the grey sediments cannot serve as parent (source) material for terra rossa evolution of the area. Relatively poor palynospectra may have resulted from flowing water transporting pollen grains out of the depocentre and/ or rapid deposition of grey sediments (hence decreased opportunities for pollen to be trapped in sediment). The latter explanation is supported also by insufficiently centered paleosecular variations. Plant assemblages indicate that the surrounding landscape was covered dominantly by temperate climatic zone riparian forest with some quite humid environments such as wetlands and ponds on a periodically flooded plain. The grey sediments could have been deposited during any warmer cycle in the Pleistocene. Nevertheless, the regional correlation, based especially on the abundance of Fagus, indicates deposition at the very beginning of the last glacial cycle in its warmer oscillation MIS 5c (ca 105-95 ka). All samples show normal magnetization. The mean paleomagnetic direction derived from well-grouped vectors representing normal polarity gave the evidence for probably slight clockwise rotation, which is less pronounced than in the nearby Krško Basin.

With respect to correlation of palynospectra with sites in the northern Mediterranean and northern Alpine foothills and the character of paleomagnetic parameters, we can conclude that the brown-yellow sediments with a paleosol horizon are products of deposition during the Eemian interglacial (MIS 5e, ca 120-112 ka) while the overlying grey sediments were most probably deposited during start of the last glaciation (Würmian), i.e., during warmer oscillation MIS 5c (W1/ca 105-85 ka).

Regarding mineralogical composition, the studied grey (partly rubified) laminated sediments have no relation with the red soils (i.e., terra rossa) in the area; and they do not represent their parent (source) material.

\section{ACKNOWLEDGEMENTS}

The co-operation of Mr. Jiří Dobrovolný (XRD analyst), Dr. Maja Andrič, Dr. Jiřina Dašková and Maryna Komar, DSc. (palynology consultations) is highly acknowledged.

The authors acknowledge the financial support from the Slovenian Research Agency (research core funding No. P6-0119). Analyses, processing and interpretation in the Czech Republic were carried out within the Research Plan of the Institute of Geology Acad Sci Czech Rep No. AV0Z30130516, Plan of the In- stitutional Financing of the Czech Acad Sci, Inst Geol No. RVO67985831, and Grants of the Grant Agency of the Academy of Sciences of the Czech Republic Nos. IAA3013201 (; IAA300130701 and Bilateral Mobility program of SAZU/Czech Acad Sci No. SAZU-16-03. Authors acknowledge fruitful comments of two reviewers for constructive suggestions and proposed corrections to improve the paper as well as Carolyn L. Ramsey for improving the use of English. 


\section{REFERENCES}

Alexandrowicz, S.W., 1987: Analiza malakologiczna w badaniach osadów czwartorzędowych.- Kwartalnik Akademii Górniczo-hutniczej im. Stanislava Staszica, Geologia, 13, 240 pp., Kraków.

Andrusov, D., Borza, K., Martiny, E. \& A. Pospíšil, 1958: O pôvode a vzniku tzv. „terra rossy“ južného a stredného Slovenska.- Geologický sborník Slovenskej akadémie vied, 9, 1:27-39.

Badía, D., Martí, C., Palacio, E., Sancho, C. \& R.M. Poch, 2009: Soil evolution over the Quaternary period in a semiarid climate (Segre river terraces, northeast Spain).- Catena, 77, 165-174.

Bavec, M., Poljak, M., Rižnar, I. \& M. Živčić, 2011: Kratek pregled geološke zgradbe Krške kotline - stanje 2011.- In: Rožič, B. (ed.) Povzetki referatov, (Geološki zbornik, 21). Univerza v Ljubljani, Naravoslovnotehniška fakulteta, Oddelek za geologijo, pp. 7-10, Ljubljana.

Bosák, P., Skála, R., Zupan Hajna, N. \& J. Dobrovolný, 2006: X-ray diffraction analyses of samples from karst sediments in Slovenia, 2. Final Report. - Unpublished Report, Inst. Geol. AS CR and Karst Res. Inst. ZRC SAZU, 171 pp., Praha-Postojna.

Bourne, M.D, Mac Niocaill, C., Henderson, G.M., Thomas, A.L. \& M.F. Knudsen, 2010: A New High-Resolution Record of the Blake Geomagnetic Excursion from ODP Site 1062.- American Geophysical Union, Fall Meeting 2010, abstract GP33B-0948.

Brus, R., 2010: Growing evidence for the existence of glacial refugia of European beech (Fagus sylvatica L.) in the south-eastern Alps and north-western Dinaric Alps.- Periodicum biologorum, 112, 3, 239-246.

Buser, S., 1974: Tolmač lista Ribnica: L 33-76: Socialistična federativna republika Jugoslavija, osnovna geološka karta, 1:100 000. Zvezni geološki zavod, 60 pp. Beograd.

Cande, S.C. \& D.V. Kent, 1995: Revised calibration of the geomagnetic polarity timescale

for the Late Cretaceous and Cenozoic.- Journal of Geophysical Research, 100, B4, 6093-6095. DOI:10.1029/94JB03098/

Carboni, S., Palomba, M., Vacca, A. \& G. Carboni, 2006: Paleosols provide sedimentation, relative age, and climatic information about the alluvial fan of the River Tirso (Central-Western Sardinia, Italy). Quaternary International, 156-157, 79-96.

Crnjaković, M., 1981: Maastrichtian flysch sediments in the south-west part of Mt. Medvednica.- Geološki vjsenik, 34, 47-61.

Drescher-Schneider, R., 2000: Die Vegetations- und Klimaentwicklung im Riß/Würm-Interglazial und im Früh- und Mittelwürm in der Umgebung von Mondsee. Ergebnisse der pollenanalytischen Untersuchungen.- Mittheilungen der Kommission der Quartärforschung, Österreichische Akademie der Wissenschaften, 12, 39-92, Wien.

Durn, G., 2003: Terra Rossa in the Mediterranean Region: Parent Materials, Composition and Origin.Geologia Croatica, 56, 1, 83-100.

Fægri, K. \& J., Iversen, 1989: Textbook of pollen analysis, fourth edition. John Wiley \& Sons, 328 pp., Chichester.

Fang, X.-M., Li, J.-J., Van der Voo, R., Mac Niocaill, C., Dai, X.-R., Kemp, R.A., Derbyshire, E., Cao, J.-X., Wang, J.-M. \& G. Wang, 1997: A record of the Blake Event during the last interglacial paleosol in the western Loess Plateau of China.- Earth and Planetary Science Letters, 146, 73-82.

Fedoroff, N. \& M. A. Courty, 2014: Revisiting the genesis of red Mediterranean soils.- Turkish Journal of Earth Sciences, 22, 3, 359-375. DOI: 10.3906/tar1210-89.

Fisher, R., 1953: Dispersion on a sphere.- Proceedings of the Royal Society, A 217, 295-305. DOI:10.1098/ rspa.1953.0064.

Follieri, M. \& D. Magri, 2001: Middle and Upper Pleistocene natural environment in the Roman area: climate, vegetation and landscape.- In: Cavarretta, G., Gioia, P., Mussi, M. \& M.R. Palombo (eds.) 1st International Congress 'The World of Elephants', 4347, Rome, Consiglio Nazionale delle Ricerche.

Gams, I., 1974: Kras (Karst).- Slovenska matica, 359 pp., Ljubljana.

Gams, I., 2004: Kras v Sloveniji v prostoru in času.Založba ZRC, ZRC SAZU, 516 pp., Ljubljana.

Gams, I. \& I. Vrišer (eds.), 1998: Geografija Slovenije.Slovenska matica, 501 pp., Ljubljana.

Gosar, A., Komac, M. \& M. Poljak, 2005: Strukturni model predterciarne podlage Krške kotline/Structural model of the pre-Tertiary basement in the Krško Basin.- Geologija, 48, 1, 23-32.

Grčman, H., Vidic, N. J., Zupan, M., Lobnik, F., Jones, A. \& L. Montanarella (eds.), 2015: Soils of Slovenia with soil map 1:250 000.- Commission Joint Research Centre (JRC)/ Publications Office of the European Union, Catalogue Number LB-NA-25212-B7-C, $152 \mathrm{pp}$.

Gregorič, V., 1969: Nastanek tal na triadnih dolomitih.Geologija, 12, 201-230.

Grimšičar, A., 1954: O montmorillonitnih glinah na Dolenjskem.- Geologija, 2, 233-241.

Habič, P., 1992: Les phénomènes paléokarstiques du karst 
alpin et dinarique en Slovénie.- In: Salomon, J.-N. \& R. Maire (eds.) Karst et évolutions climatiques: hommage à Jean Nicod. Presses Universitaires de Bordeaux, pp. 412-428, Talence.

Jelínek, V., 1966: A high sensitivity spinner magnetometer.- Studia Geophysica et Geodaetica, 10, 58-78. DOI:10.1007/BF02590052.

Jelínek, V., 1973: Precision A.C. bridge set for measuring magnetic susceptibility and its anisotropy.- Studia Geophysica et Geodaetica, 17, 36-48. DOI: 10,1007/ BF01614027.

Kirschvink, J.L., 1980: The least-squares line and plane and the analysis of palaeomagnetic data.- Geophysical Journal of the Royal Astronomical Society, 62, 699-718. DOI:10.1111/j.1365-246X.1980. tb02601.x.

Klimchouk, A.B., Sauro, U. \& M. Lazzarotto, 1996: "Hidden" shafts at the base of the epikarstic zone: A case study from the Sette Communi Plateau, Venetian Pre-Alps, Italy.- Cave and Karst Science, 23, 3, 101107.

Knez, M. \& T. Slabe, 2006: Dolenjska subsoil stone forests and other karst phenomena discovered during the construction of the Hrastje-Lešnica motorway section (Slovenia).- Acta carsologica, 35, 2, 103-109.

Kranjc, A., 1990: Dolenjski kraški svet (The Karst World of Dolenjska).- Dolenjska založba, 240 pp., Novo mesto.

Ložek, V., 1964: Quartärmollusken der Tschechoslowakei.- Rozpravy Ústředního ústavu geologického, 31, 374 pp., 32 tab., Praha.

Ložek, V., 2000: Palaeoecology of Quaternary Mollusca.Antropozoikum, 24, 35-59. Praha.

Magri, D., Vendramin, G.G., Comps, B., Dupanloup, I., Geburek, T., Gömöry, D., Latałowa, M., Litt, T., Paule, L., Roure, J.M., Tantau, I., van der Knaap, W.O., Petit, R. \& J.-L. Beaulieu, 2006: A new scenario for the Quaternary history of European beech populations: palaeobotanical evidence and genetic consequences.- New Phytologist, 171, 1, 199-221. DOI: 10.1111/j.1469-8137.2006.01740.x.

Markič, M., 2009: Pliocen in pliokvartar (Pliocene and Plio-Quaternary).- In: Pleničar, M. et al. (eds.) Geologija Slovenije.- Geološki zavod Slovenije, pp. 427-440, Ljubljana.

Mihevc, A. \& N. Zupan Hajna, 1996: Clastic sediments from dolines and caves found during the construction of the motorway near Divača, on the classical Karst. - Acta carsologica, 25, 169-191.

Otoničar, B., Slabe, T., Knez, M., Zupan Hajna, N., Prelovšek, M., Bosák, P., Skála, R. \& P. Pruner, 2006: Geološka spremljava $v$ okviru naravne dediščine: krasoslovno-speleološke, paleontološke, stratigrafske in sedimentološke značilnosti na odseku AC HrastjeLešnica.- Inštitut za raziskovanje krasa, Znanstvenoraziskovalni center SAZU, 100 pp., Postojna.

Otoničar, B., Slabe, T., Knez, M., Prelovšek, M. \& M. Perne, 2013: Geološka spremljava v okviru naravne dediščine: krasoslovno-speleološke, paleontološke, stratigrafske in sedimentološke značilnosti na pododseku AC Pluska-Ponikve.- Inštitut za raziskovanje krasa, Znanstvenoraziskovalni center SAZU, 71 pp., Postojna.

Pini, R., Ravazzi, C. \& M. Donegana, 2009: Pollen stratigraphy, vegetation and climate history of the last $215 \mathrm{ka}$ in the Zuzano Decimo core (plain of Friuli, north-eastern Italy).- Quaternary Science Reviews, 28: 1268-1290. DOI:10.1016/j.quascirev.2008.12.017.

Placer, L., 1999a: Contribution to the macrotectonic subdivision of the border region between Southern Alps and External Dinarides.- Geologija, 41, 223-255.

Placer, L., 1999b: Structural meaning of the Sava folds.Geologija, 41, 199-221.

Pleničar, M., Premru, U. \& M. Herak, 1977: Osnovna geološka karta SFRJ. L 33-79, Novo mesto, 1:100.000.Zvezni geološki zavod, Beograd.

Poljak, M. \& A. Gosar, 2001: Strukturna zgradba krške kotline po podatkih geofizikalnih raziskav $\mathrm{v}$ letih 1994-2000.- In: Horvat, A. (ed.) Povzetki referatov, (Geološki zbornik, 16). Univerza v Ljubljani, Naravoslovnotehniška fakulteta, Oddelek za geologijo, pp. 79-82, Ljubljana.

Poljak, M., Gosar, A. \& M. Živčić, 2010: Active tectonics in Slovenia.- In: Colantoni, P., Mencucci, D., Menichetti, M. \& O. Nesci (eds.): International geological congress on the Adriatic area (ADRIA 2006), Urbino, 19-20 June 2006. Geology of the Adriatic area, (GeoActa, Spec. pub. 3), Department of Earth and Geological-Environmental Sciences, University of Bologna, 15-24, Bologna.

Railsback, L.B., Gibbard, P.L., Head, M.J., Voarintsoa, N.R.G. \& S. Toucanne, 2015. An optimized scheme of lettered marine isotope substages for the last 1.0 million years, and the climatostratigraphic nature of isotope stages and substages.- Quaternary Science Reviews, 111, 94-106.

Rejšek, K., Mišičc, M. \& F. Eichler, 2012: Sustainable forestry and iron compounds in karstic soils: qualitative and semi-quantitative results focused on the occurrence of Fe-compounds on mineral particles.Journal of Forest Science, 58, 9, 410-424.

Riedel, A., 1983: Über die Aegopinella-Arten (Gastropoda, Zonitidae) aus Jugoslawien, Italien und Frankreich. - Annales Zoologici, 37, 5, 235-258, Taf. 1-2. Warszawa. 
Šercelj, A., 1961a: O kvartarni vegetaciji na Slovenskem/ On Quaternary vegetation in Slovenia.- Geologija, 7, 25-34.

Šercelj, A., 1961b: Staropleistocenska vegetacija v Zalogu pri Novem mestu.- Razprave. Slovenska akademija znanosti in umetnosti, Razred za prirodoslovne in medicinske vede, Oddelek za prirodoslovne vede, 6 , 417-434.

Šercelj, A., 1963: Razvoj würmske in holocenske gozdne vegetacije v Sloveniji.- Razprave. Slovenska akademija znanosti in umetnosti, Razred za prirodoslovne in medicinske vede, Oddelek za prirodoslovne vede, 7, 361-418.

Šercelj, A., 1965: Paleobotanične raziskave in zgodovina Ljubljanskega barja.- Geologija, 8, 5-28.

Šercelj, A., 1966: Pelodne analize pleistocenskih in holocenskih sedimentov Ljubljanskega barja.- Razprave. Slovenska akademija znanosti in umetnosti, Razred za prirodoslovne in medicinske vede, Oddelek za prirodoslovne vede, 9, 431-472.

Singer, B.S., 2014: A Quaternary geomagnetic instability time scale.- Quaternary Geochronology, 21, 29-52. DOI:10.1016/j.quageo.2013.10.003.

Smith, D.J. \& J.H. Foster, 1969: Geomagnetic reversal in Brunhes normal polarity epoch.- Science, 163, 565-567.

Verbič, T., 2004: Stratigrafija kvartarja in neotektonika vzhodnega dela Krške kotline. 1. del: Stratigrafija/ Quaternary stratigraphy and neotectonics of the Eastern Krško Basin. Part 1: Stratigraphy.- Razprave. Slovenska akademija znanosti in umetnosti, Razred za naravoslovne vede, 45, 3, 171-225.

Verbič, T., 2005: Stratigrafija kvartarja in neotektonika vzhodnega dela Krške kotline. 2. del: Neotektonika/ Quaternary stratigraphy and neotectonics of the Eastern Krško Basin. Part 2: Neotectonics.- Razprave. Slovenska akademija znanosti in umetnosti, Razred za naravoslovne vede, 46, 1, 171-216.
Vrabec, M. \& L. Fodor, 2006: Late Cenozoic tectonics of Slovenia: structural styles at the Northeastern corner of the Adriatic microplate.- In: Pinter, N. et al. (eds.) The Adria microplate: GPS geodesy, tectonics and hazards, (NATO Science Series, IV, Earth and Environmental Sciences, vol. 61). Springer, pp. 151168. Dordrecht.

Wagner, S., Günster, N. \& A. Skowronek, 2012: Genesis and climatic interpretation of paleosols and calcretes in a plio-pleistocene alluvial fan of the Costa Blanca (SE Spain).- Quaternary International, 265, 170-178.

Welter-Schultes, F.W., 2012: European non-marine molluscs, a guide for species identification.- Planet Poster Editions, 679 pp., Göttingen.

Zembo, I., 2010: Stratigraphic architecture and quaternary evolution of the Val d'Agri intermontane Basin (Southern Apennines, Italy).- Sedimentary Geology, 223, 206-234.

Zupan Hajna, N., 1992: Mineralna sestava mehanskih sedimentov iz nekaterih delov slovenskega krasa/ Mineral composition of mechanical sediments from some parts of Slovenian karst.- Acta carsologica, 21, $115-130$.

Zupan Hajna N., Mihevc A., Pruner P. \& P. Bosák, 2008: Paleomagnetism and Magnetostratigraphy of Karst Sediments in Slovenia.- Carsologica, 8. Založba ZRC SAZU, 266 pp., Postojna-Ljubljana. 